\title{
The Kinetics of Uptake and Recovery of Lanthanum using Freshwater Algae as Biosorbents: Comparative Analysis
}

\author{
Z.S. Birungi ${ }^{\mathrm{a}, 1^{*}}$, E.M.N. Chirwa ${ }^{\mathrm{a}}$ \\ ${ }^{a}$ University of Pretoria, Department of Chemical Engineering, Lynnwood Road, Private bag X20 Hatfield, \\ Pretoria 0002, South Africa
}

\begin{abstract}
In this study, the adsorption and desorption kinetics of lanthanum (La) on micro algal cells was investigated. The internal transcribed spacer (ITS) and 18S ribosomal RNA gene (rRNA) were used for molecular identification of the species. The algal species were found to have 95-98 \% identities to Desmodesmus multivariabilis, Scenedesmus acuminutus, Chloroidium saccharophilum and Stichococcus bacillaris. The species were cultured and tested independently. Desmodesmus multivariabilis was found to be the most efficient at adsorbing lanthanum with a maximum sorption capacity $\left(q_{\max }\right)$ of $100 \mathrm{mg} / \mathrm{g}$ and a high affinity $(b)$ of $4.55 \mathrm{~L} / \mathrm{g}$. Desorption of La was also highest in Desmodesmus multivariabilis with recovery up to $99.63 \%$ at initial concentration as high as $100 \mathrm{mg} / \mathrm{L}$. Desorption data fitted best to the modified pseudo second-order with a better correlation coefficient $\left(R^{2}\right)$ of $\leq 0.98$ than first order model. The results showed feasibility of lanthanum recovery using algal sorbents, a cost effective method.
\end{abstract}

Key words: lanthanum, micro algae, cell wall properties, biosorption, modelling

\footnotetext{
${ }^{1 *}$ Corresponding author. Email: zedshariff@ yahoo.com; Tel: +27 124204338
} 


\section{Introduction}

The increased demand for metals in the various industrial processes has attracted attention due to its impact on the environment and public health. Metals are nonbiodegradable in nature, and therefore accumulate in the ecosystem causing toxicity and carcinogenicity (Pahlavanzadeh et al. 2010; Ahluwalia and Goyal, 2007). In recent years, the exploitation of rare earth elements (REE) in the industrial sector is on the rise due to their unique properties and new applications being associated to these metals. Among these REEs, lanthanum (La) is one of the commonly utilised metal for making super alloys, catalysts, special ceramics, condensers (Kütahyali et al. 2010; Sert et al. 2007). The major concern of REEs is the release of mineral acids, chelating agents and fission products emanating from expired nuclear fuel into the environment (Andres et al. 2003).

REE are more abundant than many metals but their extraction involves several steps such as solvent extraction or ion exchange (Palmieri et al. 2000). Although lanthanum has a wide range of applications in the industry, knowledge about its level of toxicity and possible recovery is limited. Biosorption using readily available dead biomass is an alternative technology which has proved effective with other metals at concentrations as high as $100 \mathrm{mg} / \mathrm{L}$ (Ahalya et al. 2003; Kratochvil and Volesky, 1998). The cell wall of dead biomass has active functional groups that are responsible for binding of metals (Wang and Chen 2009). Among biosorbent materials, algae have proved to be both economic and eco-friendly, as they are abundantly available, have a high sorption capacity and potential metal recovery, (Pahlavanzadeh et al. 2010; Romera et al. 2007). 
Two mechanisms of metal removal by biomass have been observed, i.e., by transformation and uptake into the cell; by biosorption onto the cell surface with or without transformation (Nilanjani et al. 2008; Volesky and Holan, 1995). The metal species transported into a cell may require disruption of the cells to facilitate recovery. This could require energy and several processes and therefore is considered nonfeasible. On the other hand, metals adsorbed to surface of cells may be easily recovered by changing the conditions of the medium thereby reversing the adsorption process (Chojnaka, 2010). This can be achieved cost effectively under natural environmental conditions without energy inputs.

Among the algal sorbents tested for lanthanum, macro algae especially brown algae have captured most attention due to their high sorption capacity and potential for metal recovery (Vijayaraghavan et al. 2010; Diniz and Volesky, 2005). Micro algae are a diverse group of eukaryotes with thousands of species mostly found in freshwater habitats. Although these species are abundant, only a few have been investigated for their biosorption potential of REEs. In addition, recovery and re-use of REEs still remains largely unexplored (Andres et al. 2003; Korenevsky et al. 1999). This study is aimed at investigating the rate of removal and recovery of one of the ubiquitous lanthanides, lanthanum using micro algae as a biosorbent.

\section{Materials and Methods}

\subsection{Centrifuge and Streak Plating of Micro algae}

The algae used in these experiments were collected from a freshwater body in Hartbeespoort Dam, in South Africa. The freshwater micro algae was selected due to their abundance and limited exploitation for biosorption studies. A volume of $12 \mathrm{ml}$ 
micro algal sample from the enrichment culture was used. The sample was centrifuged at $5000 \mathrm{rpm}$ for 5 minutes, supernatant removed and sterile water added. The vortex mixer was used to re-suspend the cells and centrifuged again for at least 6 times. The algal samples were isolated using streak plating in axenic conditions on agar plates and left to grow for seven days under required light conditions (Osram L 36W/77 Floura) and temperature range of $20-23^{\circ} \mathrm{C}$. Repeated streaking was done to obtain single colonies free from contamination.

\subsection{Molecular Identification of Algal Species}

DNA extraction from the algal samples was performed with the CTAB method of Murray and Thompson (1980). The Internal transcribed spacer (ITS) and 18S ribosomal RNA gene (rRNA) were used in this study. ITS1 and ITS2 primers were used to amplify the ITS region in the forward and reverse directions, respectively. To amplify the $18 \mathrm{~S}$ rRNA gene, the specific forward primer and the conserved reverse primer were used. Polymerase chain reaction (PCR) amplification was carried out in a DNA Thermal Cycler (Gene Amp PCR System 2400 - Perkin Elmer). The conditions for the ITS1/ITS2 primer pair were $5 \mathrm{~min}$ at $95^{\circ} \mathrm{C}, 35$ cycles of $1 \mathrm{~min}$ at $90^{\circ} \mathrm{C}, 2 \mathrm{~min}$ at $50^{\circ} \mathrm{C}, 1$ min at $72^{\circ} \mathrm{C}$ and a final elongation step of $10 \mathrm{~min}$ at $72^{\circ} \mathrm{C}$. All PCR amplifications were performed in $50 \mu \mathrm{l}$ master mix solution containing $10 \mathrm{mM}$ Tris $\mathrm{HCl}, 50 \mathrm{mM} \mathrm{KCl}, 0.1 \%$ Triton X-100, $1.5 \mathrm{mM} \mathrm{MgSO} 4,200 \mu \mathrm{M}$ dNTP, $0.4 \mu \mathrm{M}$ of each primer, $1.0 \mathrm{u}$ Taq polymerase (Promega) and $10 \mathrm{ng}$ of total DNA. Phylogenetic analysis of sequences was checked for similarity using a basic local alignment search tool (BLAST) (http://www.ncbi.nlm.nih.gov/BLAST/). The samples identified from BLAST search were used in taxonomic classification of algae. 


\subsection{Culture and Preparation of Biosorbents}

The colonies were transferred using a loop into vials containing AF6 medium and cultured in the laboratory. The medium was prepared following the protocol underlined by Andersen et al. 2005. Chlamydomonas reinhardtii and Chlorella vulgaris were purchased from the culture centre for algae and protozoa (CCAP) for comparison purposes and was cultured in modified bold basal medium with 3 fold nitrogen and vitamins $(3 \mathrm{~N}-\mathrm{BBM}+\mathrm{V})$. The biomass was harvested after every 2 weeks, centrifuged and washed twice in deionised water before drying in an oven for 24 hours at $50^{\circ} \mathrm{C}$. The dead biomass was crashed into powder to increase the surface areas using $0.3 \mathrm{~mm}$ sieve and stored for biosorption studies.

\subsection{Equilibrium and Adsorption Kinetic Experiments}

Preliminary kinetic experiments were carried out to determine the time required for adsorption to reach equilibrium which was found to be less than 4 hours. In all the algal biomass tested, the adsorption experiments were carried out for 6 hours, time more than required for equilibrium. The effect of initial concentration of La for all the algal species was tested. A standard stock solution of $1000 \mathrm{mg} / \mathrm{L}$ of $\mathrm{La}^{3+}$ was used to prepare initial lanthanum concentrations between $15-150 \mathrm{mg} / \mathrm{L}$. These concentrations were selected with the aim of determining the highest sorption capacity of algae at low concentrations usually $\leq 100 \mathrm{mg} / \mathrm{L}$.

In equilibrium studies, the adsorbent dosage and $\mathrm{pH}$ should be kept constant. This was done with the use of a constant biomass at $0.05 \mathrm{~g}$ and optimum $\mathrm{pH}$ of 6 . The $\mathrm{pH}$ was kept constant by adjusting it hourly using $0.1 \mathrm{M} \mathrm{NaOH}$ and $0.1 \mathrm{M} \mathrm{HCl}$. Biosorption of lanthanum was found to increase with increase in $\mathrm{pH}$. Sert et al. 2007 asserts that at $\mathrm{pH}$ 
values higher than 6 precipitations occurs. Qing, 2010 and Andres et al. 2003 found the optimum $\mathrm{pH}$ between $5-7.5$ with precipitation occurring at 7.8. Kinetic experiments were carried out concurrently with equilibrium experiments after determining the time required for adsorption. In this study, the effect of different initial concentrations of $\mathrm{La}$ was tested. The initial concentrations were diluted to $100 \mathrm{ml}$ in erlenmeyer volumetric flasks and carried out in $250 \mathrm{ml}$ conical flasks. The experiments were carried out in duplicates and a control set up for all the studies tested.

The samples were stirred on a magnetic stirrer at a constant speed of $350 \mathrm{rpm}$ and room temperature. Samples were withdrawn at pre-determined time intervals for kinetic experiments and after 6 hours for equilibrium experiments. The samples were centrifuged for 10 minutes at $6000 \mathrm{rpm}$ and the filtrate analysed using the Inductively Coupled Plasma (ICP, Spectro Arcos FHS12, Boschstroisse, Germany).

\subsection{Desorption Kinetic Experiments}

Desorption kinetics were carried out using $0.1 \mathrm{M} \mathrm{HNO}_{3}$ as the eluent and metal laden biomass from adsorption experiments. The effect of initial concentration of metal loaded biosorbents for the recovery of La was tested for all the algal species. The biomass was rinsed twice in deionised water, centrifuged and weighed before experiments. Metal recovery was carried out in duplicates on the magnetic stirrer and samples taken at predetermined time intervals for up to 6 hours. Samples were centrifuged and filtrate analysed for metal recovery using the ICP. 


\subsection{Re-Use and Regeneration of Biosorbents}

The algae was tested for their re-usability for the removal and recovery of lanthanum in three cycles. The adsorption experiment was carried for 2 hours with the initial concentration of $100 \mathrm{mg} / \mathrm{L}$ lanthanum and $0.1 \mathrm{~g}$ of biomass. The sample was centrifuged and the supernatant analysed for metal analysis. The metal laden biomass was rinsed twice in deionised water and $0.1 \mathrm{M} \mathrm{HNO}_{3}$ was used as the eluent for 2 hours. The supernatant was also analysed for metal recovery. The same procedure was repeated for the other 2 cycles.

\subsection{Equilibrium Isotherms}

The Langmuir and Freundlich models are the most commonly used equilibrium isotherms in the biosorption studies due to their simplicity (Wang and Chen, 2009; Davis and Volesky, 2003). The Langmuir model is based on the assumption of a monolayer adsorption of metals on binding sites and that all metal ions interact only with one site. The Freundlich model on the other hand, assumes a heterogeneous adsorption surface with stronger binding sites occupied first with decreasing bind strength as the metal ion concentration in solution increases. The following equations (Eq.) were used to quantitatively describe the adsorption data; the amount of metal bound by the biosorbents at any contact time $(t)$ was calculated from data and is given by;

$$
\text { 国 } Q_{t}=\frac{V\left(C_{i}-C_{t}\right)}{M}
$$

where $Q=$ metal uptake $(\mathrm{mg} / \mathrm{g}) ; V=$ volume of metal solution (liters); $C_{i}=$ initial metal 
concentration $(\mathrm{mg} / \mathrm{L}) ; C_{t}=$ concentration at time $(t)(\mathrm{mg} / \mathrm{L}) ; M=$ amount of biomass (g).

The Langmuir model (1918) is expressed by the linearised equation;

$$
C_{e} / q_{e}=C_{e} / q_{\max }+1 / b q_{\max }
$$

where $q_{e}$ is the metal sorbed at equilibrium $(\mathrm{mg} / \mathrm{g}), q_{\max }$ is the maximum amount of metal sorbed $(\mathrm{mg} / \mathrm{g}), b$ is a constant related to the energy of sorption (measure of bond strength) and $C_{e}$ is the equilibrium metal ion concentration $(\mathrm{mg} / \mathrm{L})$. The Freundlich model (1907) is represented by the linearised equation as follows;

$\log q=\log K+1 / n \log C e$

where $K=$ biosorption equilibrium constant, representative of the sorption capacity; and $n$ is a constant indicative of biosorption intensity.

\subsection{Kinetic Models}

Kinetic models of first-order of Lagergren and the pseudo second-order equation were used to analyse the rate of metal sorption uptake. The first-order rate expression of Lagergren (1898) is given by the linearised equation as follows;

$$
\log \left(q_{e-} q_{t}\right)=\log q_{e}-k_{1} / 2.303^{t}
$$

Pseudo second order equation of Ho and McKay (1999) is given by the following linearised form; 


$$
t / q_{t}=1 / k_{2} q_{e}^{2}+1 / q_{e} t
$$

where, $q_{t}$ is the amount of adsorbed metal on the algal biomass at time ( $\left.\mathrm{t}\right)$ in $(\mathrm{mg} / \mathrm{g}) ; q_{e}$ is the equilibrium sorption uptake $(\mathrm{mg} / \mathrm{g}) ; k_{1}$ is the rate constant of Lagergren first-order adsorption $\left(\min ^{-1}\right)$ and $k_{2}$ is the rate constant of second-order adsorption.

Desorption kinetics were modelled using the modified equations of $1^{\text {st }}$ order and the pseudo $2^{\text {nd }}$ order equations (Njikam and Schiewer, 2012). The modified $1^{\text {st }}$ order rate equation assumes the rate of desorption is proportional to the Lanthanum filled sites and is given by differential Eq;

$d q / d t=-k_{1, d e s} q$, and

The modified $2^{\text {nd }}$ order rate equation assumes the rate of desorption is proportional to the square of Lanthanum filled sites and is given by differential Eq.;

$d q / d t=-k_{2, d e s} q^{2}$

where $k_{1, \text { des }}$ is the $1^{\text {st }}$ order desorption rate constant; $q$ is the remaining amount of metal bound to the biomass at time $t ; k_{2, \text { des }}$ the $2^{\text {nd }}$ order desorption rate constant. The differential equations 6 and 7 were integrated using the following Eq.;

$q_{n+1}=q_{n}-(d q / d t)_{n}\left(t_{n+1}-t_{n}\right)$ 
where $q_{n}$ is amount of La remaining in algae at time $t_{n}$ and $q_{n+1}$ is the amount of La at time $t_{n}$ minus the rate of desorption multiplied by the incremental time step.

\subsection{Characterisation of the Algal Biosorbents}

The morphology of the biosorbents before and after biosorption was identified using a Scanning Electron Microscope (SEM, JOEL JSM 5800LV, Tokyo, Japan). The wet algal samples were prepared using traditional chemical methods before embedding for SEM (Glauert, 1975). The samples were first rinsed three times in $0.075 \mathrm{M}$ phosphate buffer for 10 minutes. The clean cells were then fixed in $0.5 \%$ aqueous osmium tetroxide for 2 hours and rinsed three times in distilled water. Each sample was then dehydrated in ethanol $(30 \%, 50 \%, 70 \%, 90 \%, 100 \%)$ for 10 minutes. The samples were dried at critical point from liquid carbondioxide, mount on the stub and sputtered with gold ready for identification.

The functional groups on the algal cell wall were identified using the Fourier Transform Infrared (FTIR) spectrum, (Perkin Elmer 100). The instrument was set up and scanned within a range of $4000-625 \mathrm{~cm}^{-1}$. The sample holder (diamond stage) was then cleaned with acetone. The algal samples before and after adsorption were each placed on the diamond stage and the pressure arm lowered on the samples. The total pressure applied was monitored to obtain the spectrum. Data was processed with different peaks attained to represent the functional groups.

\section{Results and Discussion}

\subsection{Species Identification and Taxonomic Classification}

The results obtained from the BLAST tool after sequencing and comparison with the gene bank indicated an E-value of 0 for all the algal samples. When the E-value from 
the BLAST results is zero, then the results are good and can be accepted as the most probable species. The ITS nucleotide sequences and 18S rRNA gene exhibited a high score ranging from 862.8 - 1239.5 bits with no significant gaps, Table 1. ITS are used for predicting genetic similarities and phylogeny of the genus whereas $18 \mathrm{~S}$ rRNA provide information on differentiation of various strains (Tempesta et al, 2010). The algal species with similarities to the query samples were found to have $95-98 \%$

Table 1: Summary of BLAST Results for Molecular Identification of Micro Algae

\begin{tabular}{|c|c|c|c|c|c|c|c|}
\hline $\begin{array}{l}\text { Query } \\
\text { samples }\end{array}$ & $\begin{array}{l}\text { Score } \\
\text { (bits) }\end{array}$ & Strand & Identities & $\begin{array}{l}\% \text { of } \\
\text { identities }\end{array}$ & Gaps & Species & Description \\
\hline 1. $\mathrm{A3}$ & 1079.2 & ++ & $601 / 615$ & 98 & $5 / 615$ & \multirow[t]{3}{*}{$\begin{array}{l}\text { Desmodesmus } \\
\text { multivariabilis }\end{array}$} & $\begin{array}{l}\text { 18S rRNA gene, } \\
\text { partial sequence; }\end{array}$ \\
\hline 2. A2-P & 1048.2 & ++ & $544 / 558$ & 98 & $1 / 558$ & & $\begin{array}{l}\text { internal transcribed } \\
\text { spacer } 1,5.8 \mathrm{~S} \text { rRNA }\end{array}$ \\
\hline 3. G2-3 & 1079.2 & ++ & $601 / 615$ & 98 & $5 / 615$ & & $\begin{array}{l}\text { gene, and internal } \\
\text { transcribed spacer } 2, \\
\text { complete sequence; } \\
\text { and } 26 \mathrm{~S} \text { rRNA gene, } \\
\text { partial sequence }\end{array}$ \\
\hline 4. G2-4 & 1239.5 & ++ & $670 / 685$ & 98 & $0 / 685$ & \multirow[t]{2}{*}{$\begin{array}{l}\text { Chloroidium } \\
\text { saccharophilum }\end{array}$} & $\begin{array}{l}\text { genomic DNA } \\
\text { containing } 18 \mathrm{~S}\end{array}$ \\
\hline 5. G1-4 & 2526 & +- & $1371 / 1395$ & 98 & $1 / 1395$ & & $\begin{array}{l}\text { rRNA gene, ITS1, } \\
5.8 \mathrm{~S} \text { rRNA } \\
\text { gene, ITS } 2,28 \mathrm{~S} \\
\text { rRNA gene, culture } \\
\text { collection CCAP } \\
211 / 58\end{array}$ \\
\hline 6. A1-old & 862.8 & ++ & $645 / 679$ & 95 & $9 / 679$ & $\begin{array}{l}\text { Scenedesmus } \\
\text { acuminutus }\end{array}$ & $\begin{array}{l}\text { 5.8S rRNA gene, } \\
\text { ITS } 1 \text { and ITS } 2 \text { strain } \\
\text { UTEX } 415\end{array}$ \\
\hline 7. B1-b & 1051.1 & +- & $581 / 598$ & 97 & $0 / 598$ & $\begin{array}{l}\text { Stichococcus } \\
\text { bacillaris }\end{array}$ & $\begin{array}{l}\text { 18S rRNA gene, } \\
\text { partial sequence; } \\
\text { internal transcribed } \\
\text { spacer } 1,5.8 \mathrm{~S} \text { rRNA } \\
\text { gene, and internal } \\
\text { transcribed spacer } 2 \text {, } \\
\text { complete sequence; } \\
\text { and } 26 \mathrm{~S} \text { rRNA gene, } \\
\text { partial sequence }\end{array}$ \\
\hline
\end{tabular}


identities and these included; Desmodesmus multivariabilis, Scenedesmus acuminutus,

Chloroidium saccharophilum and Stichococcus bacillaris, Table 1.

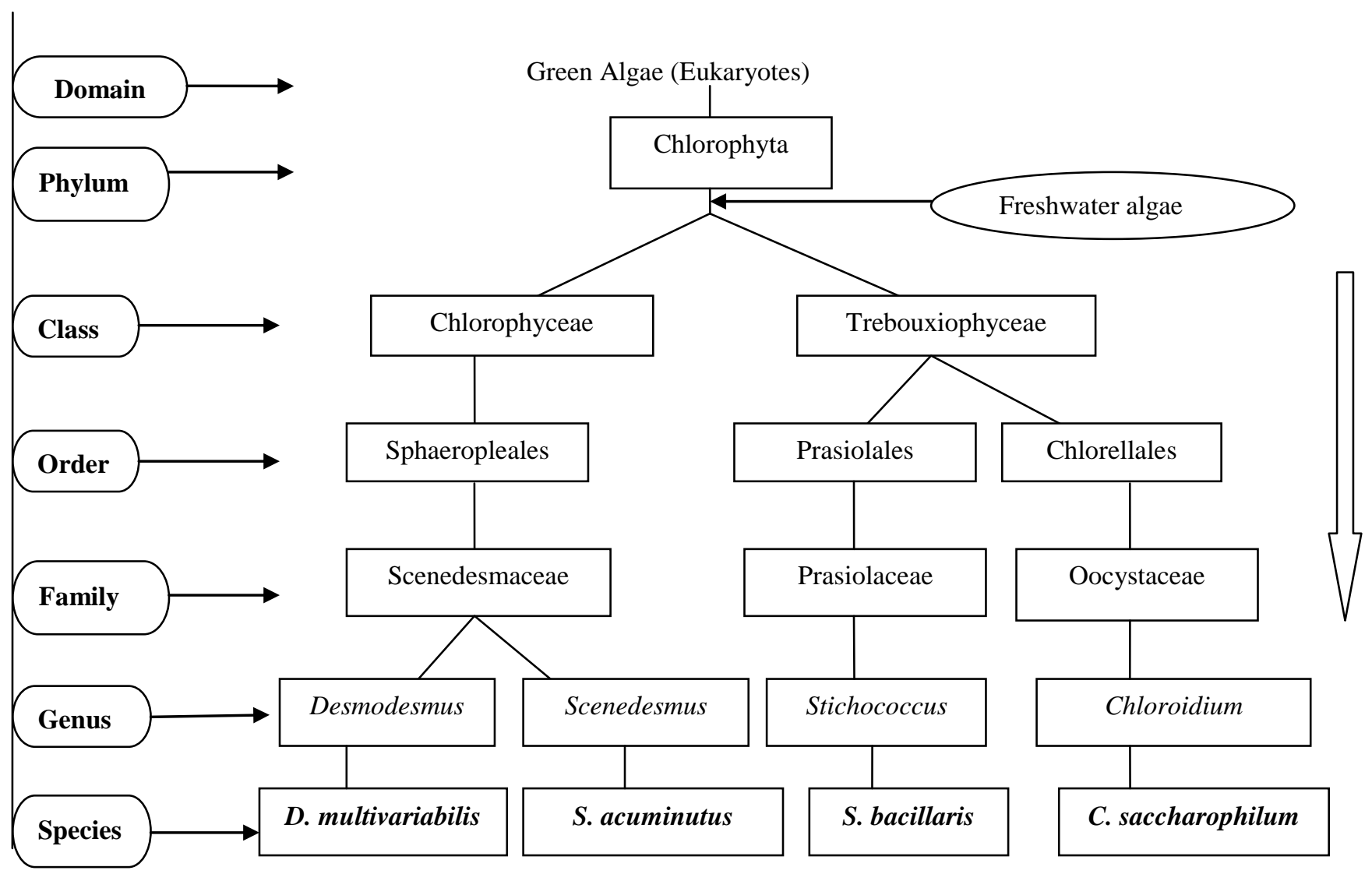

Figure. 1.Taxonomic Classification of Green Algae Based on Results from Molecular Identification

Taxonomic classification of species was done based on results obtained from the

BLAST search. The results indicated all species belonging to green algae with 2 distinct

lineages; Chloropyta and Streptophyta. Chlorophyta has majority of the known green

algae species with 4 classes; Chlorophyceae, Trebouxiophyceae, Ulvophyceae and

Prasinophyceae (Leliaert et al. 2012). From the results, the species identified belong to

2 classes of Chlorophyceae and Trebouxiophyceae, Figure 1. It can also be noted that

some species belonged to same class but with different genus. Proschold and Leliaert, 
2007 also confirmed that same species can belong to different classed with priority rule valid at the generic and species level.

\subsection{Equilibrium and Adsorption Behaviour}

Equilibrium experiments are an important step in the identification of species with the highest sorption capacity preceding any further biosorption studies. In this study, the linearised data of $C_{e} / Q_{e}$ versus $C_{e}$ were plotted from the Langmuir model (Eq. 2) as shown in Figure 2. The results from the Langmuir model had a higher correlation coefficient $\left(R^{2}\right)$ of $\geq 0.9$ than the Freundlich model with $\leq 0.8$ as shown in Table 2 . The

Table 2: Langmuir and Freundlich parameters from monometallic experiments of lanthanum on tested algal species

\begin{tabular}{llllllc}
\hline Algal species & \multicolumn{2}{c}{ Langmuir constants } & \multicolumn{3}{c}{ Freundlich constants } \\
\hline & $\boldsymbol{q}_{\max }(\mathbf{m g} / \mathbf{g})$ & $\boldsymbol{b}(\mathbf{L} / \mathbf{g})$ & $\boldsymbol{R}^{2}$ & $\boldsymbol{n}$ & $\boldsymbol{K}$ & $\boldsymbol{R}^{2}$ \\
Stichococcus bacillaris & 51.02 & 4.56 & 0.997 & 9.04 & 4.51 & 0.894 \\
Desmodesmus multivariabilis & 100 & 4.55 & 0.984 & 4.17 & 4.93 & 0.782 \\
Chlorella vulgaris & 74.60 & 0.178 & 0.995 & 3.41 & 3.66 & 0.779 \\
Scenedesmus acuminutus & 111.1 & 0.120 & 0.953 & 3.50 & 4.259 & 0.83 \\
Chloroidium saccharophilum & 129.87 & 0.142 & 0.913 & 4.06 & 4.81 & 0.807 \\
Chlamydomonas reinhardtii & 142.86 & 0.25 & 0.908 & 3.35 & 4.721 & 0.896 \\
\hline
\end{tabular}

Langmuir parameters $q_{\max }$ and $b$ represent the maximum sorption capacity and affinity respectively. Chlamydomonas reinhardtii had the highest sorption capacity with a $q_{\max }$ of $142.86 \mathrm{mg} / \mathrm{g}$ and a low affinity $b$ of $0.25 \mathrm{~L} / \mathrm{g}$ emerging the best adsorbent for lanthanum. Stichococcus bacillaris was the least effective adsorbent with the lowest $q_{\max }$ of $51.02 \mathrm{mg} / \mathrm{g}$ and highest $b$ of $4.56 \mathrm{~L} / \mathrm{g}$. 

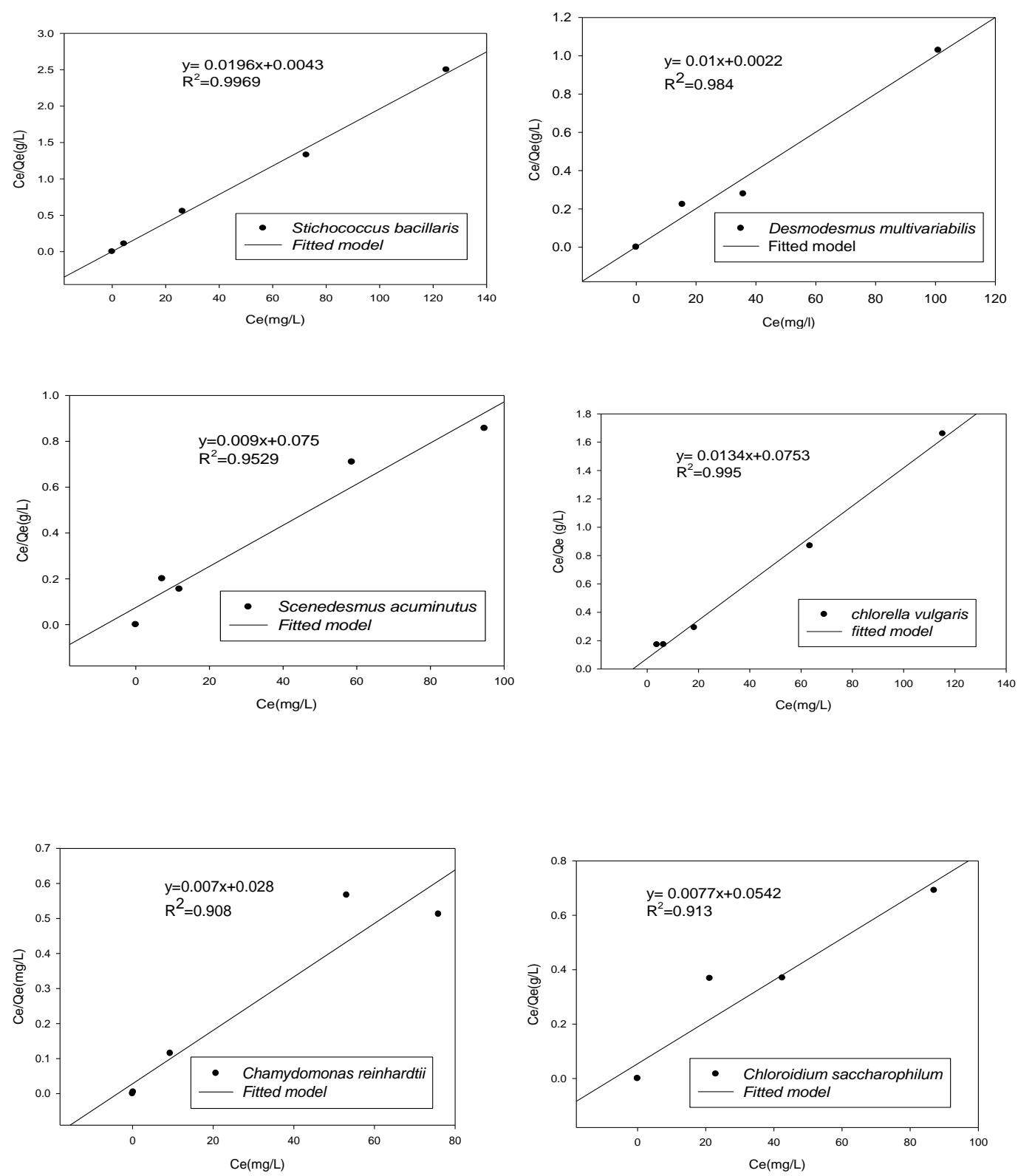

Figure.2: Langmuir isotherm models with linear plots of lanthanum uptake for the six tested algal species

The maximum sorption capacity $\left(q_{\max }\right)$ of lanthanum for the tested algae was compared to other biosorbents from previous studies. Chlamydomonas reinhardtii had a higher $q_{\max }$ of $142.86 \mathrm{mg} / \mathrm{g}$ for La as compared to other biosorbents except for Turbinaria conoides with a $q_{\max }$ of $150.5 \mathrm{mg} / \mathrm{g}$, Table 3 . It was also noted that Chlamydomonas 
reinhardtii was a more effective adsorbent than some brown algae such as sargassum species with a $q_{\max }$ of 91.68 and $139 \mathrm{mg} / \mathrm{g}$ of which is lower than $140 \mathrm{mg} / \mathrm{g}$ obtained from this study(Oliveira and Garcia, 2009; Diniz and Volesky, 2005).

Table 3: Maximum uptake $\left(q_{\max }\right)$ of lanthanum using different biomass from previous studies

\begin{tabular}{lll}
\hline Biosorbent & $\boldsymbol{q}_{\max }$ in $\mathbf{~ m g} / \mathbf{g}$ & References \\
\hline Platanus orientalis leaf powder & 28.65 & Sert et al,2007 \\
Agrobacterium sp. HN1 & 34.29 & Shuxia et al, 2010 \\
Crab shell & 140.1 & Vijayaraghavan et al, 2009 \\
Bamboo charcoal & 120 & Qing, 2010 \\
Magnetic alginate chitosan gel beads & 97.1 & Wu et al, 2010 \\
Sargassum species & 91.68 & Oliveira and Garcia, 2009 \\
Sargassum polycystum & 139 & Diniz and Volesky, 2005 \\
Iron oxide loaded calcium alginate beads & 123.5 & Wu et al, 2010 \\
Turbinaria conoides (brown algae) & 150.5 & Vijayaraghavan et al, 2010 \\
Chlamydomonas reinhardtii & 142.86 & From this study \\
\hline
\end{tabular}

On the other hand, Desmodesmus multivariabilis was found to have both a high removal and recovery rate at $q_{\max }$ of $100 \mathrm{mg} / \mathrm{g}$ and $b$ of $4.55 \mathrm{~L} / \mathrm{g}$ for La compared to other tested algae. Selection of biosorbents depends on the intended use of the species. Therefore, the study aimed at finding sorbents with a high sorption and recovery rate for La was achieved. Other authors noted that a high $q_{\max }$ and lower $b$ implies sorbents with the highest sorption capacity regardless of the recovery rate. Also a higher $q_{\max }$ and a higher $b$ imply sorbents with both a high sorption and recovery rate at low equilibrium concentration (Romera et al. 2007; Davis et al. 2003; Volesky and Holan, 1995). 


\subsection{Effect of Initial Concentration on the Removal of La}

Initial experiments were carried out to determine the effect of contact time on the concentration of lanthanum removal. The effect of initial concentration on the removal of lanthanum was high in the first 15- 30 minutes followed by a slow reduction until equilibrium was attained for all the tested algae. From the results, it can be noted that Chloroidium saccharophilum had the highest removal of La at low concentration of 15 $\mathrm{mg} / \mathrm{L}$ with over $94.34 \%$ removal in less than 15 minutes, Figure 3a. At high concentrations of $50 \mathrm{mg} / \mathrm{L}$ and $150 \mathrm{mg} / \mathrm{L}$, Chlamydomonas reinhardtii had the highest removal of La with final concentration after adsorption at $9.3 \mathrm{mg} / \mathrm{L}$ and $75.9 \mathrm{mg} / \mathrm{L}$ respectively, Figure $3 \mathrm{~b}$ and $\mathrm{c}$. Sorption efficiency decreases with increase in metal ion concentration which is due to saturation of adsorption sites (Kütahyali et al. 2010)

Biosorption is known to be a rapid process with equilibrium reached only after a few minutes and the reaction mechanism especially related to ion exchange or surface precipitation (Lee and Chang, 2011; Chojnacka et al. 2005). Adsorption mechanism depends on the concentration of anions and cations found in the solution. From the results obtained from FTIR, the most active functional groups found in all tested algal biomass were carboxyl and hydroxyl ions. The metal salt of lanthanum was prepared from nitric acid forming $\mathrm{La}\left(\mathrm{NO}_{3}\right)_{3}$. The functional groups (anions) act as sites for ion exchange with metals (cations) in this case $\mathrm{La}^{3+.}$ Ion exchange occurs at rapid kinetics with possible surface precipitation when the cell wall becomes saturated. Diniz and Volesky, 2005 also found ion exchange as the main mechanism for La adsorption using nitrate salt. 

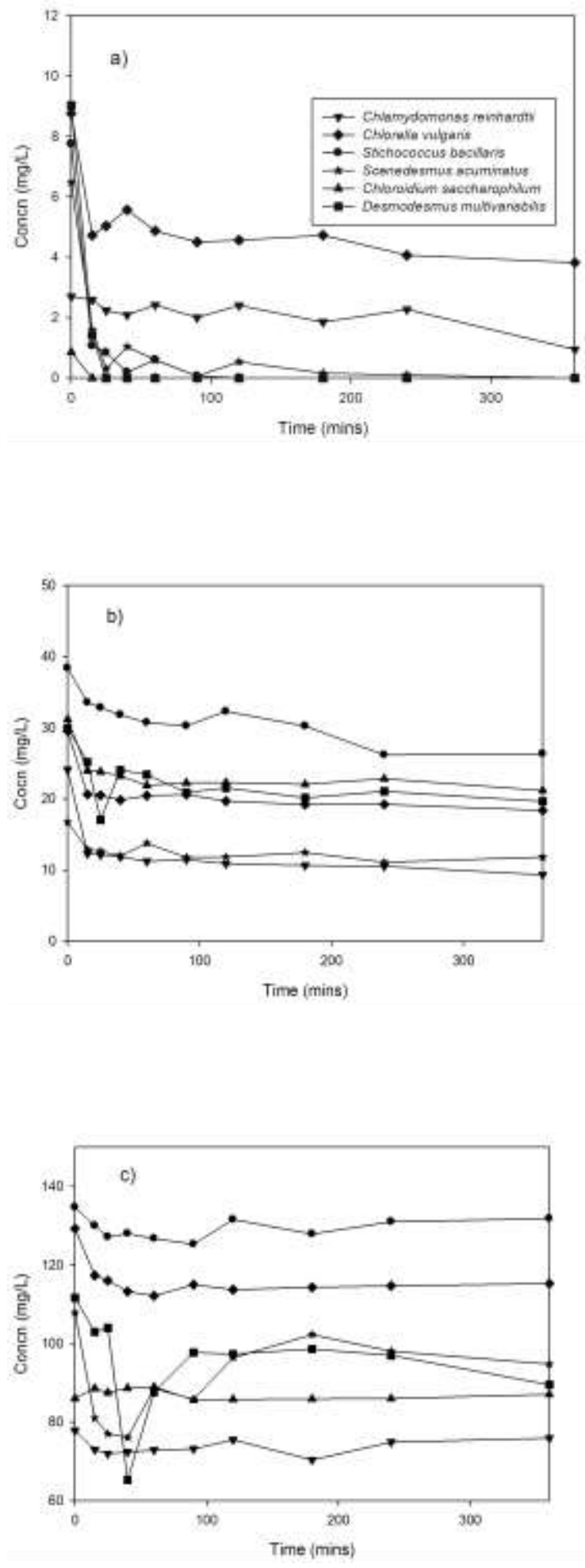

Figure. 3: Effect of Concentration Vs Time for removal of La in 6 algal species at, a) $15 \mathrm{mg} / \mathrm{L}$, b) 50 $\mathrm{mg} / \mathrm{L}$, and c) $150 \mathrm{mg} / \mathrm{L}$. 


\subsection{Adsorption Kinetic Models}

Batch kinetic models provide insight on the potential rate controlling steps that are useful when designing a full scale biosorption process. The first order and pseudo second order kinetic models are the most commonly encountered models in biosorption studies, and were used to evaluate data in this study. The kinetic models were plotted from linearised equations (Eq. 4 and 5) from which the slope and intercept were determined. The pseudo second- order model produced a stronger $R^{2}$ of $\geq 0.99$ than the first order model with $\leq 0.8$ for all the biosorbents tested, Table 4 . In addition there was no significant difference between the experimental sorption capacity $\left(q_{\exp }\right)$ and the calculated sorption capacity $\left(q_{c a l}\right)$ for pseudo second order kinetics. For example at low initial concentration of $15 \mathrm{mg} / \mathrm{L}$ of La, $q_{\text {exp }}$ and $q_{\text {cal }}$ was $30 \mathrm{mg} / \mathrm{g}$ for Stichococcus bacillaris, Desmodesmus multivariabilis, Scenedesmus acuminutus and Chloroidium saccharophilum, Table 4. At higher initial concentrations of $150 \mathrm{mg} / \mathrm{L}$, the difference between $q_{\text {exp }}$ and $q_{c a l}$ was minimal, for example Desmodesmus multivariabilis had 98.12 $\mathrm{mg} / \mathrm{g}$ and $100 \mathrm{mg} / \mathrm{g}$ respectively. The rate of reaction $\left(k_{2}\right)$ was highest at $1 \mathrm{~min}^{-1}$ for Chloroidium saccharophilum at very low concentrations of $15 \mathrm{mg} / \mathrm{L}$ of La, Table 4. This can be attributed to the highest rate of removal of La at $100 \%$ in less than 15 minutes for Chloroidium saccharophilum as compared to other tested algae, Figure 3a 
Table 4: Pseudo-second order adsorption kinetic parameters for all the tested algae at concentrations of $15-150 \mathrm{mg} / \mathrm{L}$

\begin{tabular}{|c|c|c|c|c|c|}
\hline Algal species & $\begin{array}{c}C_{i} \\
(\mathrm{mg} / \mathrm{L})\end{array}$ & $\begin{array}{l}k_{2, \text { ads }} \\
\min ^{-1}\end{array}$ & $R^{2}$ & $\begin{array}{l}q_{e} \\
\text { Experimental } \\
(\exp )(\mathrm{mg} / \mathrm{g})\end{array}$ & $\begin{array}{c}q_{e} \\
\text { Calculated } \\
\text { (cal) }(\mathrm{mg} / \mathrm{g})\end{array}$ \\
\hline Stichococcus bacillaris & 15 & 0.033 & 1.000 & 30.00 & 30.30 \\
\hline Desmodesmus multivariabilis & 15 & 0.109 & 1.000 & 30.00 & 30.30 \\
\hline Scenedesmus acuminutus & 15 & 0.018 & 0.999 & 30.00 & 30.30 \\
\hline Chloroidium saccharophilum & 15 & 1.000 & 1.000 & 30.00 & 30.30 \\
\hline Chlorella vulgaris & 15 & 0.009 & 0.998 & 22.36 & 22.73 \\
\hline Chlamydomonas reinhardtii & 15 & 0.004 & 0.996 & 28.60 & 29.41 \\
\hline Stichococcus bacillaris & 50 & 0.001 & 0.984 & 47.40 & 50.00 \\
\hline Desmodesmus multivariabilis & 50 & 0.004 & 0.998 & 69.12 & 62.50 \\
\hline Scenedesmus acuminutus & 50 & 0.015 & 0.999 & 76.43 & 76.92 \\
\hline Chloroidium saccharophilum & 50 & 0.007 & 0.998 & 57.62 & 58.82 \\
\hline Chlorella vulgaris & 50 & 0.005 & 0.999 & 63.20 & 66.67 \\
\hline Chlamydomonas reinhardtii & 50 & 0.005 & 0.999 & 81.32 & 83.33 \\
\hline Stichococcus bacillaris & 100 & 0.006 & 0.998 & 54.60 & 55.56 \\
\hline Desmodesmus multivariabilis & 100 & 0.008 & 0.999 & 128.44 & 142.00 \\
\hline Scenedesmus acuminutus & 100 & 0.002 & 0.996 & 82.66 & 83.33 \\
\hline Chloroidium saccharophilum & 100 & 0.002 & 0.996 & 115.00 & 125.00 \\
\hline Chlorella vulgaris & 100 & 0.009 & 0.995 & 73.05 & 76.92 \\
\hline Chlamydomonas reinhardtii & 100 & 0.005 & 0.998 & 93.77 & 100 \\
\hline Stichococcus bacillaris & 150 & 0.003 & 0.991 & 49.40 & 37.04 \\
\hline Desmodesmus multivariabilis & 150 & 0.002 & 0.996 & 98.12 & 100.00 \\
\hline Scenedesmus acuminutus & 150 & 0.002 & 0.991 & 110.54 & 111.11 \\
\hline Chloroidium saccharophilum & 150 & 0.156 & 0.999 & 125.91 & 126.58 \\
\hline Chlorella vulgaris & 150 & 0.009 & 0.999 & 69.46 & 71.43 \\
\hline Chlamydomonas reinhardtii & 150 & 0.003 & 0.999 & 148.20 & 166.67 \\
\hline
\end{tabular}



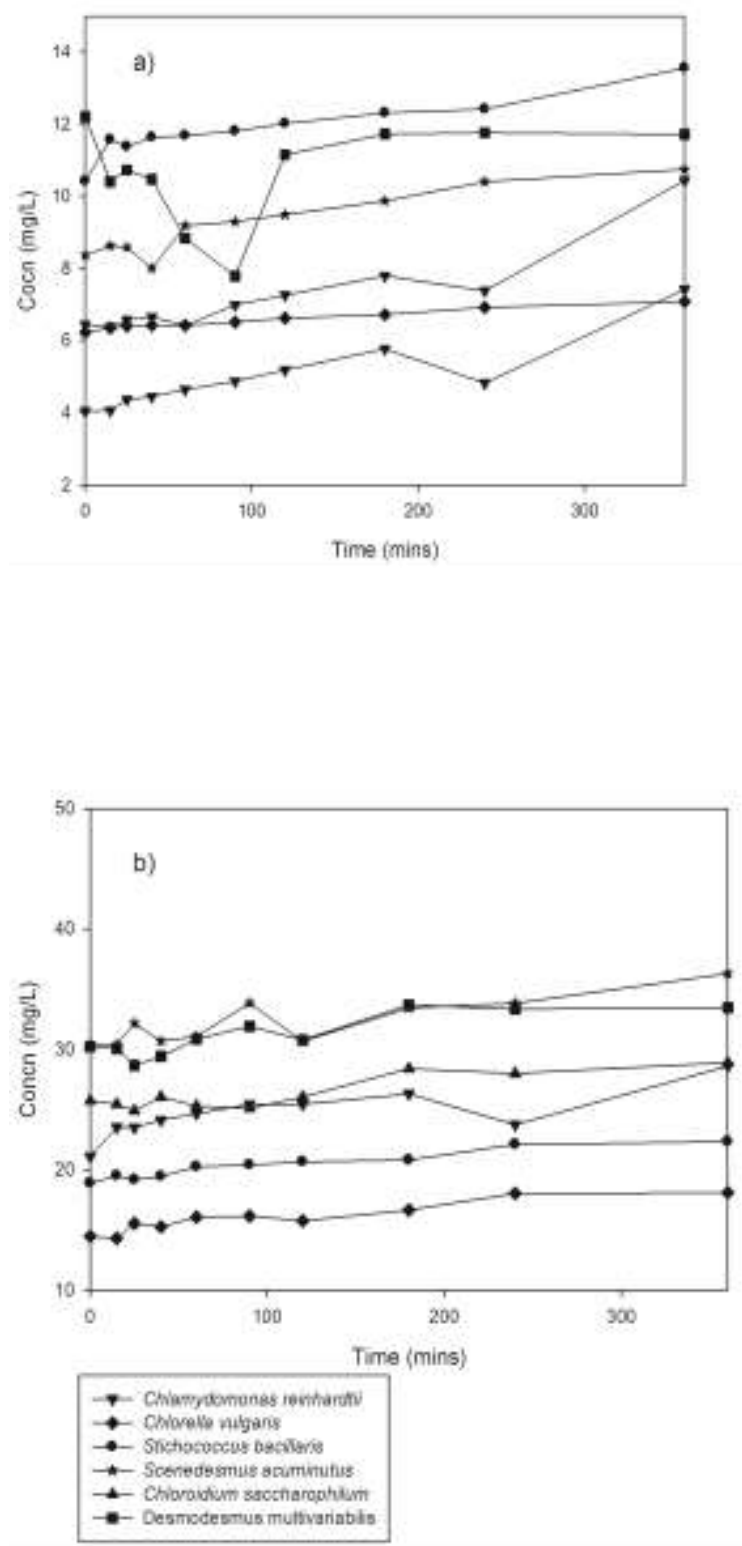

Figure. 4: Effect of Concentration Vs Time for recovery of La in 6 algal species at, a) $15 \mathrm{mg} / \mathrm{L}$ and b) $150 \mathrm{mg} / \mathrm{L}$

\subsection{Effect of Initial Concentration on the Recovery of La}

The concentration of lanthanum recovery increased with increase in time for all the species until a steady state was attained. At low concentrations of $\leq 15 \mathrm{mg} / \mathrm{L}$, desorption of La was highest for Stichococcus bacillaris and Desmodesmus multivariabilis with a final concentration recovered at 13.57 and $11.73 \mathrm{mg} / \mathrm{L}$ respectively, Figure $4 \mathrm{a}$. At 
higher concentration of $\leq 50 \mathrm{mg} / \mathrm{L}$, Chloroidium saccharophilum and Desmodesmus multivariabilis had the highest recovery of $28.9 \mathrm{mg} / \mathrm{L}$ and $33.48 \mathrm{mg} / \mathrm{L}$ at initial concentration of 29 and $34.56 \mathrm{mg} / \mathrm{L}$ respectively, Figure $4 \mathrm{~b}$. Nitric acid was used as a desorbent with a high level of $\mathrm{H}^{+}$which was replaced with $\mathrm{La}^{3+}$ found mostly in the carboxyl binding sites. Higher efficiency removal is due ion exchange of excess $\mathrm{H}^{+}$ from nitric acid (Vijayaraghavan et al. 2010).

\subsection{Desorption Kinetics and Efficiency of Metal Removal}

The adsorption kinetic models of first order and pseudo second-order were modified to fit desorption kinetics with the amount of lanthanum remaining in the algae as the rate determining concentration, Eq. 6-8. The results from the modified model showed a better $R^{2}$ of $\leq 0.98$ for the pseudo second-order model than the first order of $\leq 0.7$. In addition, the experimental $\left(q_{n}\right)$ and calculated $\left(q_{n+1}\right)$ recovery values of lanthanum were closer for pseudo second- order kinetics, Table 5. In the modified model, it is assumed that the rate of desorption is dependent of the quantity of metal-filled binding sites (Njikam and Schiewer, 2012).

The algae were tested for efficiency in regeneration and reuse. In the first cycle, recovery was highest for Desmodesmus multivariabilis at initial concentration of 100 $\mathrm{mg} / \mathrm{L}$ of lanthanum with recovery upto $99.63 \%$, followed by Chloroidium saccharophilum at $97.17 \%$, Figure 5a. In the subsequent cycles, the biomass was still reusable with a slight reduction in efficiency with removal rates still high for 

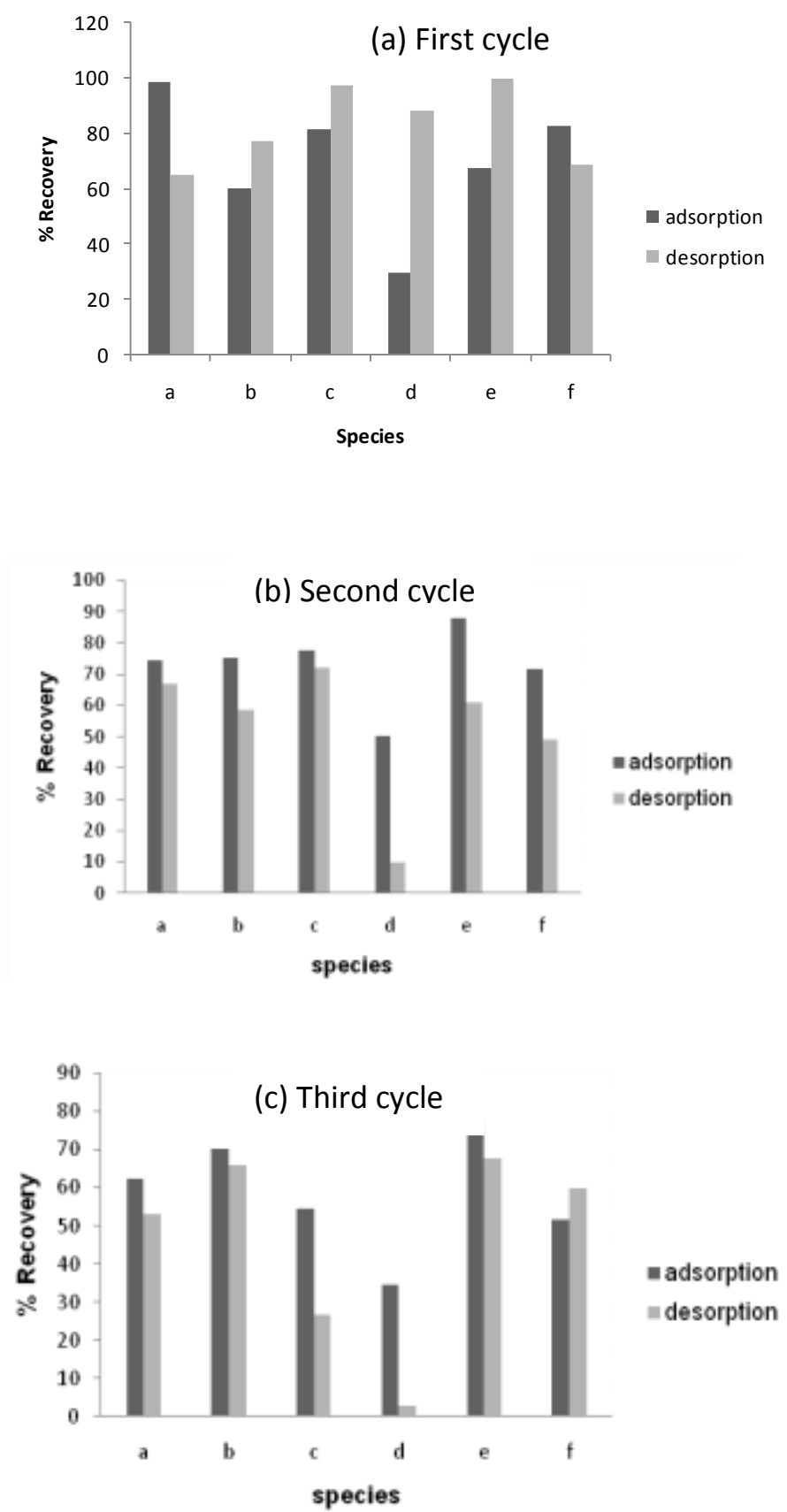

Figure. 5: Adsorption- desorption cycle of lanthanum for the six algal species; a) Chlamydomonas reinhardtii, b) Scenedesmus acuminutus, c) Chloroidium saccharophilum, d) Stichococcus bacillaris, e) Desmodesmus multivariabilis, f) Chlorella vulgaris 
Table 5: Modified Pseudo-second order desorption kinetic parameters for all the tested algae

\begin{tabular}{|c|c|c|c|c|c|}
\hline Algal species & $\begin{array}{l}\boldsymbol{C}_{\boldsymbol{i}} \\
(\mathrm{mg} / \mathbf{L})\end{array}$ & $\begin{array}{l}\boldsymbol{k}_{2, \text { des }}\left(\times 10^{-4}\right) \\
\operatorname{Min}^{-1}\end{array}$ & $R^{2}$ & $\begin{array}{l}\boldsymbol{q}_{\boldsymbol{n}} \\
(\mathrm{mg} / \mathrm{g})\end{array}$ & $\begin{array}{l}\boldsymbol{q}_{\boldsymbol{n + 1}} \\
(\mathrm{mg} / \mathrm{g})\end{array}$ \\
\hline Stichococcus bacillaris & 15 & 0.7 & 0.955 & 26.083 & 25 \\
\hline Desmodesmus multivariabilis & 15 & 0.4 & 0.911 & 41.652 & 40 \\
\hline Scenedesmus acuminutus & 15 & 0.4 & 0.945 & 41.44 & 41.67 \\
\hline Chloroidium saccharophilum & 15 & 0.2 & 0.885 & 63.024 & 66.67 \\
\hline Chlorella vulgaris & 15 & 0.4 & 0.982 & 12.843 & 12.821 \\
\hline Chlamydomonas reinhardtii & 15 & 0.6 & 0.881 & 18.586 & 19.23 \\
\hline Stichococcus bacillaris & 50 & 1 & 0.894 & 37.244 & 35.71 \\
\hline Desmodesmus multivariabilis & 50 & 0.7 & 0.963 & 42.619 & 41.67 \\
\hline Scenedesmus acuminutus & 50 & 0.7 & 0.868 & 84.357 & 83.33 \\
\hline Chloroidium saccharophilum & 50 & 0.2 & 0.891 & 86.529 & 90.90 \\
\hline Chlorella vulgaris & 50 & 0.2 & 0.878 & 40.775 & 40.00 \\
\hline Chlamydomonas reinhardtii & 50 & 0.4 & 0.911 & 43.461 & 40 \\
\hline Stichococcus bacillaris & 100 & 0.2 & 0.894 & 72.537 & 76.92 \\
\hline Desmodesmus multivariabilis & 100 & 0.3 & 0.921 & 62.981 & 66.67 \\
\hline Scenedesmus acuminutus & 100 & 0.2 & 0.877 & 64.21 & 71.43 \\
\hline Chloroidium saccharophilum & 100 & 0.3 & 0.878 & 52.498 & 50 \\
\hline Chlorella vulgaris & 100 & 0.3 & 0.857 & 29.319 & 31.25 \\
\hline Chlamydomonas reinhardtii & 100 & 0.2 & 0.943 & 56.463 & 58.82 \\
\hline Stichococcus bacillaris & 150 & 0.2 & 0.981 & 80.155 & 83.33 \\
\hline Desmodesmus multivariabilis & 150 & 0.9 & 0.855 & 60.793 & 76.92 \\
\hline Scenedesmus acuminutus & 150 & 0.9 & 0.903 & 39.34 & 45.45 \\
\hline Chloroidium saccharophilum & 150 & 0.09 & 0.859 & 193.718 & 200 \\
\hline Chlorella vulgaris & 150 & 0.4 & 0.920 & 85.992 & 66.67 \\
\hline Chlamydomonas reinhardtii & 150 & 0.03 & 0.936 & 96.433 & 100 \\
\hline
\end{tabular}

Desmodesmus multivariabilis upto $77.2 \%$, Figure $5 \mathrm{~b}$ and $\mathrm{c}$. In the $1^{\text {st }}$ cycle, however

Chlamydomonas reinhardtii showed the highest rate of removal of upto $98.44 \%$. In

some instances, there was low rate of removal for some species in the $1^{\text {st }}$ cycle compared to $2^{\text {nd }}$ and $3^{\text {rd }}$ cycle which could be attributed to the contact time allocated 
being lower than required. Stichococcus bacillaris had the lowest adsorption and desorption efficiency in all the cycles.

\subsection{SEM and FTIR Analysis}

Surface electron microscope was used in identification of the morphology of the surface on the cell wall of the algae before and after biosorption. The SEM micrographs before adsorption were found compact and smooth. There was a significant difference in the biomass surface of the cell wall after adsorption with the walls appearing rough, porous and scattered implying interaction of the metal and algal surface.

The FTIR analysis provides insight on the functional groups responsible for the biosorption mechanisms. At low frequencies, all the tested algae were found in the stretch of $1014-1035 \mathrm{~cm}^{-1}$ of wavelength implying a strong $-\mathrm{C}=\mathrm{O}$ bond of carboxylic acid, esters or ethers. Chloroidium saccharophilum, Scenedesmus acuminutus and Stichococcus bacillaris displayed a shift from $1629 \mathrm{~cm}^{-1}$ before adsorption to $1649 \mathrm{~cm}^{-1}$ after adsorption indicating an N-H medium bond for primary amines. Desmodesmus multivariabilis showed a shift from $1226-1247 \mathrm{~cm}^{-1}$ which is a C-H bond for aliphatic amines.

At higher frequencies, Chloroidium saccharophilum and Desmodesmus multivariabilis had a similar shift from $3258 \mathrm{~cm}^{-1}$ to $3300 \mathrm{~cm}^{-1}$ which is a medium $\mathrm{O}-\mathrm{H}$ stretch for carboxylic acids. Stichococcus bacillaris and Desmodesmus multivariabilis also showed a higher frequency of 2898-2941 $\mathrm{cm}^{-1}$, a C-H bond for alkanes. Scenedesmus acuminutus had a functional group of N-H stretch between $3351-3373 \mathrm{~cm}^{-1}$ for primary and secondary amines. 
In general, all the tested algae appear to have transmittance within the same wave length region with differences in adsorption volume. The gap in the adsorption volume could be due to the different components found in the biomass like proteins, carbohydrates and lipids (Lee and Chang, 2011). Wu et al. 2010 also found chlorella vulgaris and Chlamydomonas reinhardtii with similar functional groups to the tested algae of carboxyl, hydroxyl and amines.

\section{Conclusions}

In this study, Desmodesmus multivariabilis produced the best performance as a biosorbent with a relatively high uptake of $100 \mathrm{mg} / \mathrm{g}$ and high affinity of $4.55 \mathrm{~L} / \mathrm{g}$. Furthermore, the best desorbent was achieved from Desmodesmus multivariabilis with recovery greater than $99 \%$ as compared to other tested species. Stichococcus bacillaris had the least performance with the removal capacity of $51.02 \mathrm{mg} / \mathrm{g}$. The modified models for desorption fitted the experimental data with the pseudo second- order found to have a better $R^{2}$ than the first- order model. Further investigation is required on the use of the modified desorption kinetic models using different biosorbents.

\section{Acknowledgements}

The authors would like to thank the University of Pretoria Commonwealth Scholarship for the financial support rendered in the completion of this project. We would also like to thank the technical staff and research group from the Water Utilization Division for any assistance provided during this research.

\section{References}

1. Ahalya, N., Ramachandra, T.V., Kanamadi, R.D., 2003. Biosorption of Heavy Metals. Res. J. Chem. Environ 7, 4. 
2. Ahluwalia, S.S., Goyal, D., 2007. Microbial and plant derived biomass for removal of heavy metals from wastewater. Bioresource Technology 98, 2243-2257.

3. Andersen, R.A., Berges, J.A., Harrison, P.J.,Watanabe, M.M., 2005. Recipes for freshwater and seawater media, in: Andersen, R.A (Eds.), Algal culturing techniques, Elsevier, Amsterdam, pp. 429-538.

4. Andrès, Y., Texier, A.C., Le Cloirec, P., 2003. Rare earth elements removal by microbial biosorption: A Review, Environmental. Tech. 24, 1367-1375.

5. Chen, Q., 2010. Study on the adsorption of lanthanum (III) from aqueous solution by bamboo charcoal. Journal of Rare Earths, 28, 125-131

6. Chojnacka , K., Górecka , H., Chojnacki , A., 2005. Biosorption of $\mathrm{Cr}^{3}+, \mathrm{Cd}^{2+}$ and $\mathrm{Cu}^{2+}$ ions by blue green algae Spirulina $\mathrm{sp}$ : kinetics, equilibrium and the mechanism of the process, Chemosphere. $59,75-84$.

7. Chojnacka, K., 2010. Biosorption and bioaccumulation- the prospects for practical application. Environment International 36: 299-307.

8. Davis, T.H.,Volesky, B., Mucci, A., 2003. A review of the biochemistry of heavy metal biosorption by brown algae. Water Research 37, 4311-4330.

9. Diniz, V., Volesky B., 2005. Effect of counterions on lanthanum biosorption by Sargassum polycystum. Water Research 39, 2229-2236.

10. Freundlich, H. M. F., 1906. Uber die adsorption in losungen, Zeitschrift fur Physikalische Chemie (Leipzig) 57A, 385-470.

11. Glauert, A.M., 1975. Fixation, dehydration and embedding of biological specimens, in: Glauert, A.M (Eds), Practical methods in electron microscopy, North -Holland publishing, Amsterdam. 
12. Ho, Y.S., McKay, G., 1999. Pseudo-second order model for sorption processes, Process. Biochem. 34, 451- 65 .

13. Korenevsky, A.A., Sorokin, V.V., Karavaiko, G.I., 1999. Biosorption of rare earth elements. Process Metallurgy. Volume 9, 299-306.

14. Kratochvil, D., Volesky, B., 1998. Advances in the biosorption of heavy metals. Trends in Biotechnology, Volume 16, 291-300.

15. Kütahyali, C., Sert, S., Cetinkaya, B., Inan, S., Eral, M., 2010. Factors affecting lanthanum and cerium biosorption on pinus brutia leaf powder. Separation and Science Tech. 45, 456-1462.

16. Lagergren, S., 1898. Zur theorie der sogenannten adsorption geloester stoffe, Kungliga Svenska Vetenskapsakademiens. Handlingar. 24, 1-39.

17. Langmuir, I., 1918. The adsorption of gases on plane surfaces of glass, mica and platinum. J. Am. Chem. Soc. 40, 1361- 1403.

18. Lee, Y., Chang, S., 2011. The biosorption of heavy metals from aqueous solution by spirogyra and cladophora filamentous macro algae, Bioresource Technology. $102,5297-5304$.

19. Leliaert, F., Smith, D.R., Moreau, H., Herron, M.H., Verbruggen, H., Delwiche, C.F., De Clerck, O., 2012. Phylogeny and Molecular Evolution of the Green Algae. Critical Reviews in Plant Sciences. 31, 1-46

20. Murray, M.G., Thompson, W.F., 1980. Rapid isolation of high molecular weight plant DNA. Nucl. Acids Res. 8: 19, 4321-4326.

21. Nilanjani, D., Vimala, R., Karthika, P., 2008. Biosorption of heavy metals- An over view. Indian Journal of Biotechnology Vol 7, pp 159- 169. 
22. Njikam, E., Schiewer, S., 2012. Optimisation and kinetic modeling of cadmium desorption from citrus peels: A process for biosorbent regeneration. Journal of Haz. Mat. 213-214, 242-248.

23. Oliveira, R.C., Garcia Jr, O., 2009. Study of Biosorption of Rare Earth Metals (La, Nd, Eu, Gd) by Sargassum sp. Biomass in Batch Systems: Physicochemical Evaluation of Kinetics and Adsorption Models. Advanced Materials Research (Volumes 71 - 73) pp 605-608.

24. Pahlavanzadeh, H., Keshtkar, A.R., Safdari, J., Abadi, Z., 2010. Biosorption of nickel (II) from aqueous solution by brown algae: Equilibrium, dynamic and thermodynamic studies. Journal of Hazardous Materials 175, pp 304-310.

25. Palmieri, M.C., Garcia Jr, O., Melnikov, P., 2000. Neodymium biosorption from acidic solutions in batch system. Process Biochemistry 36, 441-444.

26. Proschold, T., Leliaert, F., 2007. Systematics of the green algae: conflict of classic and modern approaches, in: Brodie, J. and Lewis, J., (Eds), Unravelling the Algae: The Past, Present, and Future of Algal Systematics. CRC Press, Boca Raton, FL. pp. 123-153.

27. Romera, E., Gonza'lez, F., Ballester, A., Bla'zquez, M.L., Muñoz, J.A., 2007. Comparative study of biosorption of heavy metals using different types of algae. Bioresource Technology 98, 3344-3353.

28. Sert, S., Kütahyali, C., I’nan, S.,Talip, Z., Çetinkaya B., Eral, M., 2007. Biosorption of lanthanum and cerium from aqueous solutions by Platanus orientalis leaf powder. Hydrometallurgy. 90, 13-18. 
29. Tempesta, S., Paoletti, M.,Pasqualetti., M., 2010. Morphological and molecular identification of a strain of the unicellular green alga Dunaliella sp. isolated from Tarquinia Salterns.TWB, Transit. Waters Bull. 4: 2, 60-70.

30. Vijayaraghavan, K., Sathishkumar, M., Balasubramanian, R., 2010. Biosorption of lanthanum, cerium, europium, and ytterbium by a brown marine alga, Turbinaria conoides. Ind. Eng. Chem. Res. 49, 4405-4411

31. Vijayaraghavan, K., Mahadevan, A., Joshi, U.M., Balasubramanian, R., 2009. An examination of the uptake of lanthanum from aqueous solution by crab shell particles, Chem. Eng Journal. 152, 116-121.

32. Volesky, B., Holan, Z.R., 1995. Biosorption of heavy metals, Biotechnol. Prog. 11, $235-250$.

33. Wang, J., Chen, C., 2009. Biosorbents for heavy metals removal and their future. Biotechnology Advances 27, 195-226.

34. Wu, D., Zhao, J., Zhang, L., Wu, Q., Yang, Y., 2010. Lanthanum adsorption using iron oxide loaded calcium alginate beads. Hydrometallurgy 101, 76-83. 